International Journal of Linguistics, Literature and Translation (IJLLT)

ISSN: 2617-0299 (Online); ISSN: 2708-0099 (Print)

DOI: 10.32996/ijllt

Journal Homepage: www.al-kindipublisher.com/index.php/ijllt

IJLLT

\title{
Language Varieties of Woman's Conversation in Yutube Channel of Emma Watson in HeForShe Program: A Conversation Analysis Study
}

Dr. Ammang Latifa

Associate Professor, English Department, Graduate Program of Muhammadiyah University of Parepare, Indonesia

Corresponding Author: Dr. Ammang Latifa, E-mail: latifa_ammang@yahoo.com

\section{ARTICLE INFORMATION}

Received: November 17, 2020

Accepted: January 10, 2021

Volume: 4

Issue: 1

DOI: 10.32996/ijltt.2021.4.1.22

\section{KEYWORDS}

Language Varieties, woman's conversation, conversation analysis

\section{ABSTRACT}

Language and gender are always being exciting topics to be discussed because gender is not only about the difference between men and women based on sex, but this is about the roles and status that determine the position between men and women (Maciuszek et al., 2019). This research aims to find out some language varieties used by Emma Watson on her conversation in International women's day 2015 in HeForShe video YouTube. This research is descriptive qualitative, and to obtain the data, the researcher took the video about the conversation of Emma Watson in International women's day 2015 on YouTube channel then analyzed some language varieties. The result of this research found that there were four types of varieties of communication utilized by Emma to present her goals in the conversation. These varieties include rising intonation, intensifier, super polite form, and avoidance of strong swear words. The majority of the language variety is frequently used by Emma to show her feeling about her seriousness, her emotion, her empathy, and to firm her statement, especially about gender equality. The majority of Emma's utterances based on women's language varieties are used to show her emotion as well as her seriousness.

\section{Introduction}

Language is a tool to convey what is in our minds; language is a one of the communication tools between one another (Reboul, 2015); (Abdul Munir et al., 2019). Everyone has the way in which they deliver their language, Sociolinguistic study about this. Sociolinguistic is a field that studies how people use the language related to the social structure (Udina, 2019). Sociolinguistic is a systematic study of the social uses of language (Robutca, 2016); (Chambers, 2015).

Sociolinguistic kinds of language study talk about language and society, language and gender, language, and gender. Language and gender are always an exciting topic to be discussing (Lee, 2017). Gender is about the difference in roles between men and women, not merely about sex differences (Becker et al., 2017). Gender explains how the social position or status can determine the difference between men and women, where women can be the leader compared to men from their roles (McGinn \& Oh, 2017). In terms of gender, women may have a higher position than men (Badcock \& Stoller, 1989).

Women are unique in terms of language. Women often use specific figures in speaking in a language that is representative of what is meant and is very careful in expressing it differently than men who are firm and clear (Key \& Noble, 2017). Therefore, in between, men and women are said to speak differently in any community involving their language varieties (Van Der Slik, Van Hout, \& Schepens, 2015). One of the examples is Emma Watson; she is a woman who has a role in fighting for the rights of women. Emma Watson is an internationally famous actress who is chosen by the United Nations as a woman global goodwill ambassador. In her interview, when campaigning for HeForShe in International Women's Day 2015, there are many language varieties that she used; therefore, this research aims to find out some language varieties related to the language and gender by Emma Watson in her conversation on international women's day 2015 when campaigning HeForShe. Some women's language varieties that were
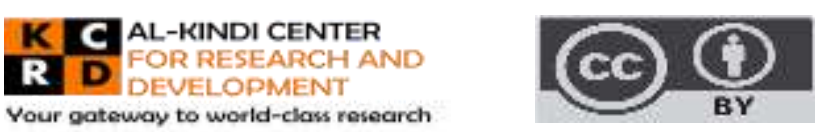

Published by Al-Kindi Center for Research and Development. Copyright (c) the author(s). This open access article is distributed under a Creative Commons Attribution (CC-BY) 4.0 license 
meant, especially about rising intonation, precise color term, intensifier, super-polite form, and avoidance of strong swear words have been considered in this study.

\section{Review of Related Literature}

\section{1 Language in Society}

The form of interaction can be reflected in the form of communication. Communication is used to convey specific intentions of one person to others through language, both verbally, in writing, and sign language. Without our language, it will be difficult to convey our intentions or goals to other people and make relationships in everyday relationships.

The idea of "language as a social institution" came from Whitney, as directed by Ferdinand de Saussure (1988a, p. 4). However, in contrast to Whitney, for Saussure, language is not the same as other social institutions, such as educational, political, and legal institutions. For Whitney, the function of these institutions - including the function of language, is more accidental, on the contrary to Saussure, although the function of other institutions is accidental, the function of language is natural. As a social institution, language is a sign system that is naturally used to express ideas; even among the existing sign systems, language is the most crucial sign system (Saussure, 1988b: 10-14). Once the importance of the language function has been deemed, so this function takes place continuously passed down from generation to generation.

A social context consists of cultural context and situation context. Cultural context is a system of values and norms that represent a belief in a particular culture. This value system includes everything that is believed to be true or false, good or bad, including ideology, which concerns social order that generally applies to culture. Meanwhile, the norm is the realization of a value system in the form of rules that control social processes, what must and must not be done by members of the community in carrying out social processes.

\subsection{Language and gender}

Language is one of the communication tools. In a language, many things can influence; one of them is gender differences (Pérez \& Tavits, 2019). Discussing gender is about not only sex differences between men and women, but also this is about the role of men and women that can influence their position in society. Language and gender focus on differences in language used by men and women (Gholami et al., 2019).

Gender plays an essential role in communicating and interacting (Correa et al.,2010; Ang, 2017; Nur, 2017). Gender, particular roles, activities, and behavior are some factors related to the way of people communicating with each other (Ellemers, 2017). Gender is about the different roles between men and women in society.

In general, the way men and women communicate is different; women are more gentle, more polite, and more emotional, while men are more forceful and more authoritative (Schmiit, 2015). Women are seen as passive or feminine, while men as active or masculine (Ranjitha G.P. \& Unnithan, 2018).

The relation between language and gender is about language that reflects gender division between men and women and also where language creates gender division, therefore, language and social structure influence each other (Jonas et al., 2017). Several issues distinguish men and women in the term of language and gender emotionally and intellectually: men are very aggressive, not emotional, independent, can hide emotion, more objective, not easily influences, and a crisis. However, women are not too aggressive, more emotional; and it is not very independent, it is hard to hide emotions, more effective, easily influenced, and easy to waver from a crisis (Piterman, 2008).

Gender is one of the factors that influence language in society anywhere in the world (Shoham et al., 2017). Gender is related to the belief process of how men and women should act and act by existing values, social, and cultural conditions (García Escribano \& Casado, 2016)

\subsection{Language identification}

The language becomes diverse and varied (note: the term variation as an English equivalent of variety is no variation). The speakers who are not only homogeneous, but also because the social interaction activities that they do are very diverse, they do not only cause the occurrence of diversity or diversity of languages. Every activity requires or causes the diversity of languages. This diversity will increase if a large number of speakers in a very wide area uses the language. 
In terms of variations in this language, there are two views. First, the variation or variety of languages is seen because of the social diversity of the speakers of the language and the diversity of the functions of the language. So variations or variations in language occur because of social diversity and diversity of language functions. If the speakers of the language are homogeneous groups, whether ethnic, social status, or employment, then the variation or diversity will not exist; that is, the language becomes uniform. Second, variations or variations of the language already exist to fulfill its function as a means of interaction in diverse community activities. Variations or variations of language can be classified based on the existence of social diversity and the function of activities in social society.

\subsection{Women's language varieties}

Women try hard in every way to raise themselves equal to men, and one of the most ways effective is to use standard language as well as possible. Because the standard variety has an educated connotation, status, quality, competent, independent, and strong (Yarnell et al., 2019). Women are more conscientious and in harmony with the norms in Sociolinguistics, and they are more openminded in the information. Men find it harder to fit in than women inside speak. Women's words are full of gossip, often reduced or added up, unreasonable/illogical, inaccurate or because of institutional factors, and often stylish (McAndrew, 2017).

In Language, the way men and women in speaking or express their ideas are the difference. Women have their styles in language; they have some characteristics in the way of language; it is called by the term women's language varieties (Shazu, 2015; (Hardison, 2017). Women's language varieties are some features that represent the characteristic of women in language, as explained (Koenig, 2018; Hardini et al., 2017). Oktapiani et al., (2017) in the project of "women's language features in female Character's utterances in the devil wears Prada Movie," they found ten women's language varieties; these are:

Lexical Hedges or Fillers, this is about hedging in women's' languages are like kinds of words, such: well...kind of..., you see...Taq Question, it is about an obvious statement and a yes-no question, such: isn't it, aren't you? don't you?

Rising intonation, it is about the intonation, between men and women there is a different pattern of intonation, where women may have rising intonation to make a firm statement.

Empty Adjectives, the speaker wants to show the emotional connection between the speaker and the listener, such lovely, cute, pretty or great, fresh, and so on.

The precise color term is to name or mention color, in order to interpret color, such: lavender, aquamarine, maroon, or beige. The intensifier is used to strengthen the meaning of the statement, such: quite, really, so, hypercorrect Grammar is used because women must be polite and avoiding slang languages in order women use standard grammar form.

Super Polite Form, such: would you please..., could you give me...., Dear...,Oh....

Avoidance of strong swear words, such: oh dear..., goodness

Emphatic Stress, such: what a beautiful dress! Or what a performance!

\subsection{Emma Watson in HeForShe of video You Tube}

Emma Watson is a famous actress who is starring many kinds of Hollywood movies; one of them is in Harry Potter as Hermione. Harry Potter, the movie was brought Emma to one of the best actresses in Hollywood, even in the world. Everyone knows Emma thanks to her fantastic role in Harry Potter; this movie has brought Emma to the top of her career. Emma became so admired by many fans, is famous not only gave a happy life to Emma, but this backfired when sometimes there were people who saw Emma from a different angle, which made her sometimes feel harassed. This feeling makes Emma struggle for gender equality, especially for women, so that men can respect and respect the existence of women.

Emma is a woman goodwill ambassador since 2014 to advocate for the empowerment of young women. As a famous actress, Emma often feels things that are not even fun but harassment. Therefore, Emma is always struggling with how to get women valued and respected, get the same place as men. Therefore, to dedicate her efforts towards the empowerment of young women, Emma was chosen as an advocate for UN Women's HeForShe campaign in promoting gender equality.

Emma Watson is one of the actresses who care about Gender equality; she even participated in the HeForShe campaign. HeForShe is solidarity campaigns to encourage men to participate in realizing gender equality and ending violence against women. Emma, in her conversation in HeForShe in International women's Day 2015, gave a very memorable speech, a stirring speech, incredible speech about gender equality. (https://www.facebook.com/emmawatson/). 


\section{Research Methodology}

This research was a descriptive qualitative method in order to collect data; the researcher analyzed a collection of Emma Watson's utterances in HeForShe conversation with Emma Watson in International Women's Day 2015. The data was taken from YouTube video about a conversation of HeForShe program with Emma Watson in International Women's Day 2015. The data then analyzed to find some women's language varieties used by Emma Watson based on Lakoff's (1973).

The researcher firstly watched the video of Emma Watson in HeForShe of Women's International Day 2015. From YouTube, then transcript the conversation to make the researcher easy to analyze it; after transcribing the conversation, the researcher then analyzed one by one the women's language varieties based on Layoff's theory of the conversation of Emma Watson in Women's International Day 2015 about HeForShe.

\section{Results and Discussion}

\subsection{Result}

The findings of the study revealed that there are ten women's language varieties, but the researcher only analyzed five of them, these are rising intonation, precise color term, Intensifier, Super Polite Form, and Avoidance of strong swear words because these five types represent the characteristic of women, especially in the term of language and gender.

Analysis 1

Example data

Data 1. " And I don't think that's what feminism is about at all."

Data 2. "um...women...women have so much to offer."

Data 3. "um...make a change."

The type of these utterances occurred 37 times, which is used by Emma Watson to confirm her statement if her statement is accurate; In the theory of Lakoff that women used as rising intonation. This type explains that women usually use a high intonation then men to make a confirmation statement (Lakoff,1973).

Analysis 2

Example data

Data4. I really wanted to try to reach as many different people as possible in a very short space of time.

Data 5. It is insane. So many people

Data 6. I really do! I think it's been such an amazing tool for me because I can instantly and directly share things that are really important to me, and it's really personal. Therefore, it is nice to be able to do that. Really nice.

These type utterances are the second most frequent type use by Emma Watson. There is 119 times occurrence by Emma Watson utterances, examples data. The finding of this analysis showed that women always use intensifier in their statement to show how serious they are and to show their emotion because in society, sometimes, women's voice is unheard. Women usually like to interpret colors, but this type not found in Emma Watson's utterances.

Analysis 3

Example data

Data 7. "Please" in her conversation and no other found, such."

Data 8. "Please, if you are a man........"

Data 9. "Please, please let me know."

This type showed that women consider politeness in their utterances, and the finding of this research shows that three times these typically occur in Emma Watson's utterances. The use of the word 'please" is used by Emma to show that she was making a request; 
she hopes something, especially about gender equality. Based on the Lakoff theory, in this case, Emma Watson used a super polite form.

Analysis 4

Data 10 "....Oh My God!"

Data 11 "Gosh......"

Emma uses the word "Oh My God" to convey her emotional feeling and with the word "Gosh" to show her emotion and her annoyance about the same position between men and women but with the pay gap. Therefore, women show their emotions politely. This type is about women usually use softer language forms such as "oh dear" or "oh God". The finding of this research shows that Emma also avoids to use strong swear words by using softer words such: this kind of language gender varieties called Avoidance of strong swear words

\subsection{Discussion}

From the results of the analysis of a number of sample data, the results of this study discuss gender discourse according to his view not because of his own gender, arguments raised between whether or not the gender should be questioned. Regarding gender, there is no need to be questioned if there are no more differences, injustice, sub-ordination or the imbalance of roles between men and women in society. As an example, illustrated in data analysis 1;

Data 1. "And I don't think that's what feminism is about at all."

Data 2. "um...women...women have so much to offer."

Data 3. "um...make a change.".

The three types of utterances that were raised at the time of interview were with rather high intonation. This test gives comfort makes no difference between men and women who have the potential to make a difference in the present. This response reflects the preacher trying to refuse to attend discourses that often question the differences between men and women.

Discussion and discuss gender, which discusses who brought the program. The long history of facilitating the role and struggle of women through their universal languages is not concerned about their character and ability to be compared to men in the sense of the specific language of their speech.

Research on the use of language, especially politeness about gender, shows inconsistency. These inconsistencies appeared at research conducted by West. West's study of conversations between doctors and patients shows that male doctors interrupt twice as often as their patients. However, female doctors are more often interrupted by male patients (West in Kuntjara, 2012: 67). These findings indicate that the act of actually interrupting the conversation is a form of domination of the person who interrupts the interrupted person. A person's status also does not seem to affect because even if a female doctor has a higher social status than her male patient, she still gets more frequent interruptions. So, a person's gender seems to be more influential than one's status. However, a linguistic student from Petra Christian University, Surabaya, also examined conversations between doctors and patients, as did West. The result was not like that obtained by West. Female doctors are the same as male doctors: they interrupt patients more often. Although the results of the student's final project research cannot be used as a benchmark and this can be taken into consideration regarding the study of the relationship between language and gender.

In the course of history recorded many writings in a specific way or specifically told the social status of women both in regional and national contexts that are quite high, as well as the political role of women also experience things that are not much different from men. A survey conducted by Coates (in Malmkjær, 2012: 302) on various studies on the influence of gender of speakers on linguistic variation shows that there are speeches that are exclusively preferred by women and other speeches that are exclusively preferred by men. For example, in interactions between genders, women, in general, ask more questions, use more polite speech, and interrupt fewer conversations than men. In contrary to the myth that women talk more than men, the findings of several studies show that men hear less and talk more than women (Catalan, 2003: 55). In data analysis 2, Ema Watson emphasized herself through her speech-language, that she was also able to do many things that did not take as long as anyone else or men could do. His speech is done with enough emotional who tries to show his ability should not be underestimated. 
Analysis 2

Example data

Data4. I really wanted to try to reach as many different people as possible in a very short space of time.

Data 5. It is insane. So many people

Data 6. I really do! I think it's been such an amazing tool for me because I can instantly and directly share things that are really important to me, and it's really personal. Therefore, it is nice to be able to do that. Really nice.

The various communication abilities of gender in regions also cannot be separated from the customary context that occurs in the community. Regarding discussions regarding gender, including gender equality and justice, according to experts, there are two main theories, namely the theory of nurture and the theory of nature. In the development era, experts developed a new concept as an instrument to analyze gender, namely the theory of balance or the theory of equilibrium. The relationship between these three theories can be explained interdependently; nurture theory is the result of social and cultural formation. So theories should not be able to exist in their interactions. To control the harmony of the nurture theory as an instrument, namely the equilibrium theory, the primary basis of this theory is to build balance in society. Also, this equilibrium theory also adopts an assumption that these two theories are like two sides of a platfom currency that cannot be separated and cannot be debated. Theory hopes that in practice it complements where there are deficiencies, so that there is no longer a conflict between genders, but what happens is balanced equality, the effectiveness of the combination of these two theories greatly affects the empowerment of gender.

\section{Conclusion}

Based on the finding of this research there are ten women's language varieties elaborated in Emma Watson in International Women's Day 2015 about HeForShe. Among the ten of language varieties, there are only four of types found in Emma Watson's utterances; these are rising intonation, intensifier, super polite form and avoidance of strong swear words. However, this research did not find the language production variety of precise color as introduced by Lakoff (1973) .

The majority of the language variety is frequently used by Emma to show her feeling about her seriousness, her emotion, her empathy, and to firm her statement, especially about gender equality. She cares about women's rights.

Politeness in language and solidarity by a woman is inseparable from the patterns in the speaker's language, this is related to language behavior in daily activities. There is politeness that can be accepted according to the speaker and there is also politeness in language that is not accepted according to the speaker. Politeness is also related to someone's intelligence in having a sense of language that is triggered by the diversity in language (language variety). For example, someone who will communicate and interact with others should be able to choose the vocabulary and language intonation that will be used in order to be polite to the other person. Therefore, in conducting conversations or interactions with other people, especially people who have cultural differences. We should pay attention to language cultural ethics or politeness in language and solidarity by seeing whom the other person is talking to, in the context of the situation in which the conversation takes place and what the topic of conversation is and pay attention to solidarity between people.

\section{References}

[1] Abdul Munir, K., Tarman, Nur, A., \& Harun, M. (2019). Using Language Experience Approach (LEA) and Talk Massage Symbol Visible (TMSV) Method in Learning of Speech Skill of Indonesia Students. Journal of Educational \& Social Research, 9(4), 58-65. https://doi.org/10.2478/jesr2019-0055

[2] Ang, C. S. (2017). Internet habit strength and online communication: Exploring gender differences. Computers in Human Behavior, 66, 1-6. https://doi.org/10.1016/j.chb.2016.09.028

[3] Badcock, C., \& Stoller, R. J. (1989). Presentations of Gender. The British Journal of Sociology, 40(2), 350. https://doi.org/10.2307/590283

[4] Becker, J. B., McClellan, M. L., \& Reed, B. G. (2017). Sex differences, gender and addiction. Journal of Neuroscience Research, 95(1-2), 136147. https://doi.org/10.1002/jnr.23963

[5] Chambers, J. K. (2015). Sociolinguistics. https://doi.org/10.1002/9781405165518.wbeoss204.pub2

[6] Correa, T., Hinsley, A. W., \& de Zúñiga, H. G. (2010). Who interacts on the Web?: The intersection of users' personality and social media use. Computers in Human Behavior, 26(2), 247-253. https://doi.org/10.1016/j.chb.2009.09.003

[7] Ellemers, N. (2017). Gender Stereotypes. The SAGE Encyclopedia of Psychology and Gender. https://doi.org/10.4135/9781483384269.n251

[8] García Escribano, J. J., \& Casado, A. B. F. (2016). Construction in gender differences of the discourse of entrepreneurship. Psychobiological, cultural and familiar aspects. Suma de Negocios, 7(15), 18-24. https://doi.org/10.1016/j.sumneg.2015.12.003 
[9] Gholami, R., Koohzad, A., Ghonsooly, B., \& Ghapanchi, Z. (2019). Relationship between Students' Gender and their Use of Politeness Strategies in the "Results and Discussions Section" of PhD Dissertations. Dinamika Ilmu, 19(1), 75-95. https://doi.org/10.21093/di.v19i1.1475

[10] Hardini, T. I., Darmawangsa, D., \& NADA, A. G. (2017). a Study of Women'S Language Varieties in French Movie. Francisola, $2(2), 134$. https://doi.org/10.17509/francisola.v2i2.9404

[11] Hardison, A. (2017). Achieving Literacy Excellence Through: Identifying and Utilizing High Yield Strategies. 1-256.

[12] Jonas, K. J., Cesario, J., Alger, M., Bailey, A. H., Bombari, D., Carney, D., ... Tybur, J. M. (2017). Power poses-where do we stand? In Comprehensive Results in Social Psychology (Vol. 2). https://doi.org/10.1080/23743603.2017.1342447

[13] Key, L. E. B., \& Noble, B. P. (2017). Course in General Linguistics. In Course in General Linguistics. https://doi.org/10.4324/9781912281732

[14] Koenig, A. M. (2018). Comparing prescriptive and descriptive gender stereotypes about children, adults, and the elderly. Frontiers in Psychology, 9(JUN). https://doi.org/10.3389/fpsyg.2018.01086

[15] Lakoff, R. (1973). Language and Woman's Place. Language in Society, 2(1), 45-80. https://doi.org/10.2307/4166707

[16] Lee, T. (2017). Gender dynamics in romantic and antiromantic popular music.

[17] Maciuszek, J., Polak, M., \& Świątkowska, N. (2019). Grammatical Gender Influences Semantic Categorization and Implicit Cognition in Polish. Frontiers in Psychology, 10(October), 1-18. https://doi.org/10.3389/fpsyg.2019.02208

[18] McAndrew, F. T. (2017). How "The Gossip" Became a Woman and How "Gossip" Became Her Weapon of Choice. The Oxford Handbook of Women and Competition (Forthcoming), (November), 191-205. https://doi.org/10.1093/oxfordhb/9780199376377.013.13

[19] McGinn, K. L., \& Oh, E. (2017). Gender, social class, and women's employment. Current Opinion in Psychology, $18,84-88$. https://doi.org/10.1016/j.copsyc.2017.07.012

[20] Nur, D. R. (2017). The Analysis of The Feminist Characters in Kate Chopin's "The Awakening." JEES (Journal of English Educators Society), 2(1), 1. https://doi.org/10.21070/jees.v2i1.687

[21] Oktapiani, Ti., Natsir, M., \& Setyowati, R. (2017). Women's language features found in female character's utterances in the devil wears prada movie. Ilmu Budaya (Jurnal Bahasa, Sastra, Seni \& Budaya), 1(3), 220.

[22] Pérez, E. O., \& Tavits, M. (2019). Language influences public attitudes toward gender equality. Journal of Politics, 81(1), 81-93. https://doi.org/10.1086/700004

[23] Piterman, H. (2008). Women in Management the Leadership Challenge. Retrieved from https://www.dss.gov.au/sites/default/files/documents/05_2012/report_march08.pdf

[24] Ranjitha G.P., and Unnithan, A. B. (2018). Self \& Identity of Being an Ideal Woman: An Exploratory Qualitative Study. IIM Kozhikode Society and Management Review, 7(1), 33-44. https://doi.org/10.1177/2277975217733883

[25] Reboul, A. C. (2015). Why language really is not communication system: cognitive view of language evolution. Frontiers in Psychology, 6(September), 1-12. https://doi.org/10.3389/fpsyg.2015.01434

[26] Robutca, M. (2016). Systemic Functional Linguistics as a Macro-sociolinguistics Framework:The Stages of Development. Studies in Linguistics,(38), 471-492. https://doi.org/10.17002/sil..38.201601.471

[27] Schmiit, D. (2015). Are Women More Emotional Than Men? Retrieved from https://www.psychologytoday.com/us/blog/sexualpersonalities/201504/are-women-more-emotional-men

[28] Shazu, R. I. (2015). Relationship between Gender \& Language. Journal of Education \& Practice, 5(14), 93-100. Retrieved from https://www.hbs.edu/faculty/Publication Files/McGinnOh_GenderSocialClass_COPSYC_495_201708001331892896_75165458-c7d9-495ab87b-cc77fe85ded1.pdfiew/12994/13307

[29] Shoham, A., Almor, T., Lee, S. M., \& Ahammad, M. F. (2017). Encouraging environmental sustainability through gender: A micro-foundational approach using linguistic gender marking. Journal of Organizational Behavior, 38(9), 1356-1379. https://doi.org/10.1002/job.2188

[30] Udina, N. (2019). Mobility Paradigm In Sociolinguistics Studies: Language Of International Labour Migration. (February), 4-6.

[31] Van Der Slik, F. W. P., Van Hout, R. W. N. M., \& Schepens, J. J. (2015). The gender gap in second language acquisition: Gender differences in the acquisition of Dutch among immigrants from 88 countries with 49 mother tongues. PLOS ONE, 10(11), 1-22. https://doi.org/10.1371/journal.pone.0142056

[32] Yarnell, L. M., Neff, K. D., Davidson, O. A., \& Mullarkey, M. (2019). Gender Differences in Self-Compassion: Examining the Role of Gender Role Orientation. Mindfulness, 10(6), 1136-1152. https://doi.org/10.1007/s12671-018-1066-1 